\title{
Ancient Jewish Greek Practices of Reading and Their Material Aspects
}

The traditional characterisation of ancient Judaism as text-centred and thus as a 'religion of the book' is a common narrative: The 'old' sacrificial cult of the temple was substituted after 70 CE by a 'literary cult' with the rabbinic emphasis on prayer and especially on studying and reading Hebrew Scripture. The resulting 'bookish' nature of Rabbinic Judaism remains mostly unchallenged in recent scholarship and this is partly also true for biblical Judaism. Studies both on historical reading practices and on other forms of textual reception have long been neglected in Biblical Studies and scholarship of Second Temple Judaism due to their focus mainly on the development of what would later become the Jewish Bible, on textual criticism and scribal practices. However, the afore-mentioned 'literary cult' and practices of reading in communities of ancient Judaism have to be put into their historical context of reception and mapped more precisely. The following issues have to be examined: The preconditions of reading (presence and distribution of texts; literacy; orality and textuality; secondary and magical use of Scripture); the texts read in ancient Jewish literature, also with regard to languages and translations; the material aspects of reading (esp. format: scroll); and the identification of different communities of reading.

The basic assumption of my paper as part of my $\mathrm{PhD}$ project on mapping reading practices in ancient Judaism is that reading practices and textual reception differ in various sociocultural contexts, epochs, and geographical areas. Reading is understood as a "complex sociocultural construction that is tied, essentially, to particular contexts". ${ }^{1}$ In order to contextualise ancient Jewish reading practices, my paper focuses on three different topics against the background of Hellenistic and Greek speaking Jewish communities in antiquity:

(1) It will briefly question the perception of ancient Judaism as a 'religion of the book' since it can be argued that neither broad knowledge nor distribution of Scripture, nor Torah reading as lectio continua in synagogues can be taken for granted in ancient Judaism.

1 Johnson 2000, 600.

This publication originated in the Collaborative Research Centre 933 "Material Text Cultures. Materiality and Presence of Writing in Non-Typographic Societies" (subproject B04 "Scholarly Knowledge, Drollery or Esotericism? The Masora of the Hebrew Bible in its Various Material Properties"). The CRC 933 is funded by the German Research Foundation (DFG). I would like to thank Hanna Liss (Heidelberg) for giving helpful advice and discussing my paper, and Aurélie Bischofberger (Lausanne) for improving my English. Abbreviations used in this paper: IJO I = Noy et al. 2004; IJO II = Ameling 2004; CIJ I = Frey 1936; NewDocs 8 = Llewelyn 1998; JIGRE = Horbury/Noy 1992.

Ә Open Access. (C) 2020 Jonas Leipziger, published by De Gruyter. (c) BY-NC-ND This work is licensed under the Creative Commons Attribution-NonCommercial-NoDerivatives 4.0 License. 
(2) Concerning the synagogal development of regular and public readings of Torah, it will shortly show that a monolingual Greek reading can be assumed in an Greek speaking environment from its origins in the first centuries CE, to its broad distribution in the fourth century, and up to its hebraisation (sixth/seventh century).

(3) Recent scholarship has argued for an unbroken continuity of a Jewish usage of the Greek Bible from Antiquity up to the Middle Ages and beyond (esp. Nicholas de Lange). The core of my paper takes part in these debates, focussing on the first centuries CE in seeking to fill the gap between Hellenistic Judaism and the early Middle Ages. It will discuss the attribution of some Greek Bible codices to a Christian origin. According to common scholarship, criteria for assessing their origin include the format of the codex, the scribal practice of the so called nomina sacra, and the use of Greek language. All three criteria are supposed to be unique to Christian manuscripts as opposed to Jewish. This method of identification has been questioned by Kurt Treu ${ }^{2}$ and Robert A. Kraft. ${ }^{3}$ My paper presents evidence of ancient artefacts (manuscripts, esp. codices; amulets; inscriptions) that may lead to the conclusion of a Jewish origin and usage of some of these Greek Bible codices.

Jewish cultural history in Antiquity has often been studied mainly on the basis of Rabbinic narratives. However, scholarship done in the last decades has increasingly questioned the use of Rabbinic literature as describing actual historical events, traditions, and customs. ${ }^{4}$ Moreover, the actual influence of the Rabbinic movement is challenged in different ways: Rabbinic norms and traditions do not necessarily represent all forms of ancient Judaism. Thus in describing ancient Jewish reading practices, Rabbinic sources like Mishnah, Talmud Yerushalmi, Talmud Bavli, or the extra-canonical tractates like Sefer Torah or Soferim cannot be taken for granted as reflecting actual historical customs of reading Torah in the synagogues or in the Rabbi's study houses. Nevertheless, many studies on Jewish practices of reading use these Rabbinic sources as historical testimonies. As a result, they risk projecting Rabbinic norms anachronistically on earlier periods, undertaking a 'rabbinisation' of all forms of Judaism(s) in Antiquity, or ignoring Greek speaking Judaism given the Rabbinic preference for the Hebrew language.

In concentrating on Greek speaking Jewish communities in Antiquity and on their practices of reading and by reconstructing them through meta-texts about reading and through material evidences, my paper seeks to describe ancient Jewish practices of reading more precisely.

2 Cf. Treu 1973.

3 Cf. Kraft 2003.

4 Cf. Hezser 2010. 


\section{Ancient Judaism as 'Religion of the Book'?}

It is a popular commonplace to label ancient Judaism as being a 'religion of the book'. One of my working theories is that ancient Judaism, defined as a 'religion of the book' and thus exhibiting elements of a 'literary cult', would require firstly an established ritual, i.e. ritualised and regular readings of Scripture/Torah as lectio continua, and secondly it requires a wide distribution of these texts. However, neither broad knowledge nor distribution of Scripture, nor Torah reading as lectio continua in synagogues can be taken for granted in ancient Judaism.

\subsection{Presence and Distribution of Scripture in Ancient Judaism}

Albert Baumgarten ${ }^{6}$ characterises Torah as a "public document" and as "possession of all Jews, known and available to them", 7 so that Jews in Antiquity regarded their Scriptures as 'public'. ${ }^{8}$ Similarly, e. g. Martha Himmelfarb, ${ }^{9}$ Stefan Schorch, ${ }^{10}$ and Joachim Schaper ${ }^{11}$ presume both a historically determinable public access and a wide distribution of Torah in the second century BCE. Moreover, Schorch assumes that in the third and fourth century BCE private ownership and distribution and also public access to manuscripts of Torah have been common. ${ }^{12}$ However, the public access to and wide distribution of Scriptures postulated by Baumgarten, Himmelfarb, Schorch, Schaper, and others have to be questioned: the topos of Torah as a widely known, distributed, and public document seems to be rather a literary fiction than describing historical realities. Both biblical Judaism until the first centuries CE and the subsequent Rabbinic Judaism reflect rather an educated and literate elite than a common or widespread "religion of the book" as characterising the masses of Jews in Antiquity. Only after the spread of a ritual that popularises and promulgates Torah-i. e. the regular reading of Torah-the Jewish Scriptures in Antiquity became wider known and left the circles of the elites. Private ownership of Torah scrolls remains an exception in Antiquity..$^{13}$ The multitude of scrolls found among the Dead Sea Scrolls and the rituals of studying scripture described in some communal texts should rather be seen as a

5 Cf. for example Wischmeyer 1995, 17; Assmann 2010, 104-109; Pietsch 2011; Schmid 2012.

6 Cf. Baumgarten 1985; Schorch 2004, 54-61; Schorch 2007; Schremer 2001; Carr 2005, 247; Schiffman 1999; Levine 2005, 148; Schwartz 2001, 49.

7 Baumgarten 1985, 17.

8 Cf. Baumgarten 1985, 22.

9 Cf. Himmelfarb 2013, 225.

10 Cf. Schorch 2009a, 2009b, esp. 171-174.

11 Cf. Schaper 2007.

12 Cf. Schorch 2009b, $173 f$.

13 Cf. Hezser 2001, 2003. 
peculiarity of the community of the yahad than as a general characteristic of Second Temple Jewish communities. ${ }^{14}$

These arguments against a public access to and wide distribution of Torah have been put forward by Catherine Hezser, ${ }^{15}$ Günther Stemberger, ${ }^{16}$ Rebecca Scharbach Wollenberg, ${ }^{17}$ and Michael Satlow. ${ }^{18}$ Stemberger summarises about the pre-70 CE period that Torah and other Biblical books have not been available to the public. ${ }^{19}$ According to him, Torah was anything but a public good of the people. It remained the exclusive property of priests and the elite of ancient Judaism that was read only very rarely in the public. ${ }^{20}$

\subsection{The Development of Ritualised Readings of Torah as Lectio Continua}

The most important feature in ancient Jewish synagogues were regular, public, and ritualised readings of Torah. With respect to the act of reading, Daniel Boyarin emphasises the difference between ancient Jewish and modern practices: "Reading', in ancient Jewish culture signifies an act which is oral, social, and collective, while in modern (and early-modern) Europe it signifies an act that belongs to a private or semiprivate social space." ${ }^{21}$ Questions on geographical origin, distribution, and the precise dating of reading Torah as lectio continua are disputed. ${ }^{22}$ Some scholars assume that regular readings are already established either in the Babylonian exile or in Second Temple Judaism: Levine considers public reading in the first century CE as a universal practice of ancient Judaism that has been institutionalised between the fifth and third century BCE and became a central part of the synagogue. According to him, the translation of the Hebrew Bible into Greek in the third century BCE is also evidence of the emergence of regular Torah readings. ${ }^{23}$ Similar arguments are put forward by Gelardini ${ }^{24}$ and Runesson, according to whom public readings date from the fifth century BCE and are attested in biblical sources like the books of Ezra and Nehemiah. ${ }^{25}$ Watts even dates the origin of public readings to the times of the Israelite monarchy. ${ }^{26}$

14 Cf. Stemberger 2012b, 29; Hezser 2001, 426.

15 Cf. Hezser 2001.

16 Cf. Stemberger 2012b.

17 Cf. Scharbach Wollenberg 2015.

18 Cf. Satlow 2014.

19 Stemberger 2012b, 34.

20 Cf. Stemberger 2012b, 28.

21 Boyarin 2003, 61.

22 Cf. esp. Schiffman 1999; Mosser 2012; Watts 1995; Shinan 1987; Perrot 1990.

23 Cf. Levine 2005, $150 f$.

24 Cf. Gelardini 2007, 113.

25 Cf. Runesson 2001, 240-233.

26 Cf. Watts 1995, 557. 
Among the biblical verses describing readings of Scripture, especially Neh 8, 2 Kgs 22:8-13, and Deut 31:9-13 are debated. However, according to other interpretations of these biblical narratives, the evidence does not describe any tradition of ritualised public readings as lectio continua of Scripture: the biblical accounts describe one-time-events, if they are testified as historical facts at all or are better understood as literary fictions. ${ }^{27}$ With regard to the first century CE, a number of sources like the Theodotus-inscription, Philo, Josephus, and the New Testament testifies the nascent transformation process from rituals of studying Scripture to regular, public, and ritualised practices of reading Torah. However, a widespread diffusion of these traditions can in no ways be taken for granted in ancient Judaism:

\begin{abstract}
The evidence surveyed appears to me to attest the custom of regular public reading from scripture in the Diaspora by the beginning of the Common Era. But unambiguous evidence for this practice in first-century Judah is minimal. The scanty evidence would seem to make it difficult to assume that the custom was widespread in the latter land. And for earlier Second Temple times we have only a few biblical and other passages reflecting at most an occasional, sporadic practice of public recitation of scripture. Given the absence of schools in ancient Judah [...] only regular public reading of the Bible (or recitation of the contents of biblical and related literature) could fill the role of a mass medium needed to disseminate a socially constructed national identity among the people. And our sources do not clearly attest such a practice before the first century. ${ }^{28}$
\end{abstract}

A related issue is the question of origins, diffusion, and purpose of ancient Jewish synagogues. ${ }^{29}$ Schwartz emphasises that the institution of the synagogue becomes a widespread phenomenon with "more than marginal significance" 30 only in the fourth century CE. In short, the assumption of regular and public reading practices of ancient Judaism as lectio continua appears to be questionable for a long period of time: "So what do we actually know about Torah reading practices in the first century? What do we know about instruction during Sabbath assemblies? The answer to both of these questions is this: not what most scholars of early Judaism and Christianity have presumed." ${ }^{31}$ Thus, it becomes clear that regular and public practices of reading cannot be taken for granted in ancient Judaism and that the ritual setting, format, and design was not uniform in the first centuries CE: This is especially true for the language of the recitation and the reading format, and these topics will be discussed in the following chapters.

27 Cf. Japhet 2015, 187; Stemberger 2012b, 28; Schiffman 1999.

28 Goodblatt 2006, 40.

29 Cf. Levine 1987; Runesson 2001; Levine 2005; Hachlili 2013.

30 Schwartz 2001, 216.

31 Mosser 2012, 550. 


\section{Material Aspects of Reading: Evidence for Ancient Jewish Greek Bible Codices and Their Ongoing Usage}

Manuscripts are not only 'containers' of text: In contrast, they should be understood as script-bearing artefacts that determine and shape acts of reading. ${ }^{32}$ First and foremost, this paper deals with material aspects of scrolls and codices. The common narrative that describes the shift from scroll to codex implies that while the early Christians rapidly adopted the codex the Jews did not use the codex and held on to the scroll until the eighth or ninth century and thus until the rise of Islam. With regard to the scroll, the tractates Sefer Torah and Sofrim contain detailed prescriptions of producing and writing the Sefer Torah on a scroll for synagogal usage. ${ }^{33}$ Consequently T.-S. 6H9-6H21, a papyrus containing Joseph bar Nissan's Shaveh-Kiriathaim and dated palaeographically to the eighth century, is regarded as the first codex of Jewish scribal culture, while the first codex containing the Jewish Bible is seen in the Codex Cairensis. While its date is being discussed and partly questioned, the earliest unchallenged colophon of a Jewish Bible codex is to be found in a codex fragment dated to 903/04 that contains parts of the books of Ruth and Nehemiah. Against this background of Hebrew Jewish scribal culture and material evidence, Catherine Hezser assumes that "there is no evidence that a codex [...] was used by Jews prior to the Christians, if it was used by Jews at all in Antiquity." ${ }^{34}$ Similarly, Willem Smellik writes that the "codex [...] seems to have come into use among Jewish circles only after the Arab conquest, with a possible exception for a non-Biblical text in Greek". ${ }^{35}$ David Stern expresses the same opinion. ${ }^{36}$

According to this interpretation of scribal culture, there seems to be a clear cut Parting of the Ways with regard to material aspects of reading: The format of the codex would be an early identity marker of the Christian movement, while Jews did not use the codex before the eighth or ninth century. However, this perception of ancient Jewish and early Christian history has to be questioned: possible Jewish manuscripts of the Greek Bible (LXX or Jewish revisions/recensions) are neglected, since scholarship (possibly influenced by the Rabbinic narratives) focuses mainly on Hebrew manuscripts. This is true both with regard to the codex as a possible format of Jewish scripture in Antiquity and to the ongoing (liturgical) Jewish usage of the Greek Bible. Before presenting evidence for both a possible Jewish origin of some Greek Bible codices from the second/third century CE onwards and for a continuous Jewish use of

32 Cf. Hilgert 2010.

33 Cf. Cohen 1965a; 1965b.

34 Hezser 2001, 136.

35 Smelik 2013, 222.

36 Cf. Stern 2008, 163-165. 
Greek Bibles in synagogal readings, I want to emphasise the risk of characterising the use of the codex as a distinct marker of difference between ancient Jewish and early Christian communities. This characterisation runs the danger of perpetuating anachronistic views on the Parting of the Ways and of projecting later Rabbinic norms on earlier periods, and risks neglecting the Jewish Greek heritage of Hellenistic Judaism.

Scholarship on ancient Judaism and early Christianity of the last decades has lead to a radical re-evaluation of the Parting of the Ways, reformulated as Ways that never Parted..$^{37}$ The developing Christian movement is regarded more and more as a Jewish movement and its Jewish roots, heritage, and embeddedness in ancient Judaism are highlighted. The developments of both Christianity as a distinct entity and of ancient Judaism and Rabbinic Judaism are regarded as a result of different discourses lead by patristic and Rabbinic elites. While different studies argue for long shared traditions regarding theology, thought, and ritual where Christianity and Judaism cannot be considered as separate entities before the fourth or fifth century CE, the interpretation of the material evidence and especially of Greek Bible manuscripts seems to be a surprising exception to these discourses arguing for an early Parting of the Ways. It seems to be a broad scholarly consensus-whether explicitly or implicitly-that all of the preserved manuscripts of the Greek Bible (LXX) are of Christian origin, while hardly any Jewish Bible manuscript can be traced back to the time when Christianity arose in the first centuries CE. Although in studies on the Greek Bible/Septuagint the Jewish origin of the Greek translation of the Hebrew Bible in the third century BCE is noted, it often seems that this narrative highlights both the Christian takeover and therefore the Jewish rejection of its Greek Bible heritage.

According to the 'checklist' just mentioned, nearly every codex of the Greek Bible is considered as being of Christian origin with the exception of only a few manuscripts. If this narrative were indeed true, this perception of a clear-cut 'material' Parting of the Ways would be quite astonishing, given the appearance of codices of the Greek Bible in the second century already. In order to challenge this common scholarly perception, we need to examine the criteria by which a Jewish origin and usage of Greek Bible codices is excluded, and these are-as already mentioned-the codex form, the nomina sacra, and the Greek language.

\subsection{Nomina Sacra in Jewish Artefacts}

My paper focuses on the earliest manuscripts of the Greek Bible that-with a few earlier exceptions ${ }^{38}$-date from the first centuries CE, i. e. parallel to the development of the beginnings of the Christian movement. In evaluating these Greek Bible codices

37 Cf. Becker/Reed 2003.

38 Pre-Christian, Jewish manuscripts of the Greek Bible include: 4Q LXXDeut; Papyrus Rylands 458; Papyrus Fouad 266; 4Q LXXLeva; 4Q LXXLev' 4Q LXXNum; 7QLXXEpJer; 7Q LXXEx (and as well 8HevXIIgr. as P.Oxy. 3522, dated to the first century CE). 
(and some scrolls), the scribal feature of the so called nomina sacra led to identify them as Christian: The so called nomina sacra are Greek abbreviations by contraction with a super-linear stroke. They replace titles, names and terms regarded as holy and represent them for example as $\overline{\kappa \varsigma}$ or $\overline{\theta \varsigma}$, instead of their uncontracted forms kúpı $\theta \varepsilon$ ć. It was in 1907 that Ludwig Traube, the German Jewish philologist and palaeographer, wrote his ground-breaking monograph on Nomina Sacra: Versuch einer Geschichte der christlichen Kürzung ${ }^{39}$ and called these Greek abbreviations nomina sacra. While Traube argued not only for a Jewish use but also for a Jewish origin of the nomina sacra, a scholarly consensus arose in the 1960s and 1970s on a Christian origin of this scribal practice. Even more, nomina sacra are perceived commonly as the characteristic feature of early Christian manuscripts of the Greek 'Old Testament' (LXX), of what would later become the Christian New Testament, and of the New Testament Apocrypha. Nomina sacra became almost identity markers of Christian artefacts, proving Christian provenance and excluding Jewish use and origin. This scholarly consensus is only challenged by Kurt Tre $\mathrm{u}^{40}$ and by Robert A. Kraft. ${ }^{41}$ Most scholars seem to establish a 'checklist' of three items allowing them to prove the Christian origin of a manuscript: firstly, the codex-format, since Jews never used the codex before the eighth/ninth century but exmployed only scrolls for liturgical readings; secondly, the occurrence of nomina sacra (abbreviations through contractions, like $\overline{\kappa \varsigma}$ or $\overline{\theta \varsigma}$ ), ${ }^{42}$ for which a Jewish origin is generally excluded; and thirdly, the use of Greek language, since only Hebrew is seen as the Jew's holy language according to the Rabbinic ideology. ${ }^{43}$ This essentialist form of categorisation and of constructing orthodox/orthoprax criteria of difference between ancient Jewish and early Christian communities of reading led Roberts to label both the codex and the nomina sacra as "the two stigmata of Christian texts". ${ }^{44}$ This will turn out as an anachronistic approach to the material evidence and heritage of both ancient Judaism and early Christianity.

To build on the work done by Treu and Kraft, there is more evidence of nomina sacra in undoubtful Jewish artefacts than commonly acknowledged in the history of research. ${ }^{45}$ Concerning the origin of the nomina sacra, a clear answer cannot be

39 Cf. Traube 1907.

40 Cf. Treu 1973.

41 Cf. Kraft 2003.

42 Cf. Traube 1907; Howard 1977; Roberts 1979; Hurtado 1998; Hurtado 2006, 96-98; Kraft 2003.

43 Already Treu 1973, 140, wrote: "Wie steht es mit jüdischen Texten aus christlicher Zeit? Wir haben inzwischen eine große Anzahl griechischer Texte des Alten Testaments, darunter auch nicht wenige aus dem 2. und 3. Jh. Soweit ich sehe, ist nie systematisch nachgeprüft worden, ob unter ihnen nicht Stücke jüdischer Herkunft sind. Drei Axiome dürften eine solche Prüfung verhindert haben: 1) Nach Übernahme der LXX durch die Christen gaben die Juden sie auf. Handschriften aus nachchristlicher Zeit müssen daher christlich sein. 2) Juden schrieben nur Rollen. Kodizes müssen daher christlich sein. 3) Die Kontraktion der sog. Nomina sacra ist ein spezifisch christlicher Gebrauch. Ihr Vorkommen beweist christliche Herkunft." Cf. also Kraft 2002.

44 Roberts 1979, 19.

45 The number of studies on nomina sacra is vast. The most important contributions to the history of 
provided. But in terms of reception history, the inscriptions, amulets and cult objects presented here argue for an indisputable Jewish use of nomina sacra: the presence of nomina sacra in Jewish artefacts is given in the table below. The evidence is classified as amulets, cult objects, and inscriptions. It also includes Hebrew artefacts containing in my opinion Hebrew equivalents to the Greek nomina sacra that have not been treated so far:

Tab. 1: Nomina Sacra in Jewish Artefacts.

\begin{tabular}{|c|c|c|c|c|}
\hline Dat. & Artefact & Lang. & Form & Nomina Sacra \\
\hline$I I / I I I$ & $\begin{array}{l}\text { Siracusa, Museo } \\
\text { Archeologico Nazio- } \\
\text { nale, without inventory } \\
\text { number }{ }^{46}\end{array}$ & G & $\begin{array}{l}\text { Amulet (contains Deut 32:1-3 } \\
\text { according to the ancient Greek } \\
\text { version of Aquila) }\end{array}$ & $\underline{\underline{K u}}$ \\
\hline IV/V & $\begin{array}{l}\text { Brooklyn Museum, } \\
41.684(=\text { JIGRE 134) }\end{array}$ & G & Cultic object: incense burner & $\overline{\mathrm{K \varepsilon}}$ \\
\hline $300-350$ & IJO I, Ach58 & G & $\begin{array}{l}\text { Mosaic inscription of Theodorus, } \\
\text { Aegina }\end{array}$ & $\bar{\theta} u$ \\
\hline $360-370$ & See Note ${ }^{48}$ & & $\begin{array}{l}\text { Dedicatory inscription, Synagoge, } \\
\text { Sardis }\end{array}$ & $\overline{\Theta u}$ \\
\hline $\mathrm{V} / \mathrm{VI}$ & P.Köln Inv. $5941^{49}$ & H & Papyrus, Hebrew lamentation & אים/האים/ל י, י, \\
\hline $\mathrm{VI} / \mathrm{VII}$ & $\begin{array}{l}\text { Jerusalem, Israel } \\
\text { Museum, unknown } \\
\text { inventory number }{ }^{50}\end{array}$ & G & $\begin{array}{l}\text { Byzantine amuletic armband } \\
\text { (partly modificating the ancient } \\
\text { Greek versions of Aquila, Symma- } \\
\text { chus, and Theodotion in transla- } \\
\text { ting Deut } 6: 5-9 ; 11: 13-21 \text { ) }\end{array}$ & $\overline{\mathrm{K} \zeta}$ \\
\hline IV & IJO I, Ach72 & G & $\begin{array}{l}\text { Inscription, prayer of Eunomius, } \\
\text { Grammata Bay (Syros) }\end{array}$ & $\overline{\kappa \varepsilon} \beta \circ \eta \dot{\theta} \eta$ \\
\hline IV & IJO I, Ach73 & G & $\begin{array}{l}\text { Inscription, thanksgiving of Heor- } \\
\text { tylis, Grammata Bay (Syros) }\end{array}$ & $\overline{\theta u}$ \\
\hline $\mathrm{IV}(-\mathrm{VI})$ & IJO I, Mac17 & G & $\begin{array}{l}\text { Dedicatory inscription, Synagoge, } \\
\text { Thessalonike (LXX Num 6:22-27) }\end{array}$ & $\overline{\mathrm{k \zeta}}, \overline{\ln \lambda}, \theta \varepsilon o ́ \varsigma$ \\
\hline
\end{tabular}

research include chronologically Traube 1907; Paap 1959; Skeat 1969; Brown 1970; Treu 1973; Turner 1977; Howard 1977; Roberts 1979; Gamble 1995; Hurtado 1998; Hurtado 2000; Kraft 2003; Hurtado 2006; Hurtado 2010; Hurtado 2012; Bagnall 2009; Edwards 2009.

46 Cf. Brea 1956, 170f.; Kotansky 1994, $129 f$.

47 Cf. Horbury/Noy 1992, 225 (= 134); Weitzmann 1979, 385.

48 Cf. Edwards 2009; Kroll 2001, 30f.

49 Cf. Klein-Franke 1983; Sirat 1985, Pl. 4; NewDocs 8, 145.

50 Cf. Benovitz 2016. 
Tab. 1: (continued).

\begin{tabular}{|c|c|c|c|c|}
\hline Dat. & Artefact & Lang. & Form & Nomina Sacra \\
\hline IV- & IJO II 226 & G & Funerary inscription, Ikonion & $\theta \varepsilon, \theta v$ \\
\hline V & BSHE0010 51 & G & $\begin{array}{l}\text { Synagogue Mosaic, dedicatory, } \\
\text { Scythopolis-Beth Shean }\end{array}$ & K \\
\hline V & BSHE0011 ${ }^{52}$ & G & $\begin{array}{l}\text { Synagogue Mosaic, dedicatory, } \\
\text { Scythopolis-Beth Shean }\end{array}$ & K \\
\hline $\mathrm{V}-\mathrm{VI}$ & CAES008053 & G & $\begin{array}{l}\text { Block, dedicatory (offering), } \\
\text { Caesarea }\end{array}$ & $\mathrm{K} \varsigma \beta$ \\
\hline VI & CIJ I 661 & G & Funerary inscription [?], Tortosa & $\overline{\mathrm{KY}}$ \\
\hline VI & BSHE0016 $6^{54}$ & G & $\begin{array}{l}\text { Synagogue Mosaic, dedicatory, } \\
\text { Scythopolis-Beth Shean }\end{array}$ & Ks \\
\hline $\mathrm{VI} / \mathrm{VII}$ & CIJ 1141 & G & $\begin{array}{l}\text { An Offering of the Jewish congra- } \\
\text { gation }\end{array}$ & $\overline{\mathrm{K} \Sigma} \mathrm{B}[\Sigma$ \\
\hline $604 / 5$ & ASHK000255 & G & $\begin{array}{l}\text { Dedication on Synagogue grate, } \\
\text { marble plaque, Ashkelon }\end{array}$ & $\theta \beta, \theta \omega$, Kup, \\
\hline$?$ & MS. Heb. c. $57(P)(c)^{56}$ & $\mathrm{H}$ & Papyrus, liturgical [?] & : [?] \\
\hline$?$ & T-S $8 \mathrm{H} 16.23^{57}$ & $\mathrm{H}$ & Prayer & יי' אינו \\
\hline$?$ & T-S C6.13358 & G & Commentary on 1 Kings & $\bar{\eta}$ \\
\hline ? & T-S NS $122.126^{59}$ & G & Passover Haggadah & $\bar{\pi}$ \\
\hline
\end{tabular}

51 Database Inscriptions of Israel / Palestine "BSHE0010-Scythopolis-Beth Shean, 5th c. CE. Synagogue Mosaic. Dedicatory,” http://library.brown.edu/cds/projects/iip/viewinscr/bshe0010/ (last accessed 10.06.2018).

52 Database Inscriptions of Israel / Palestine "BSHE0011-Scythopolis-Beth Shean, 5th c. CE. Synagogue Mosaic. Dedicatory,” http://library.brown.edu/cds/projects/iip/viewinscr/bshe0011/ (last accessed 10.06.2018).

53 Database Inscriptions of Israel / Palestine "CAES0080-Caesarea. Fifth or sixth century CE. Block. Dedicatory (Offering)," http://library.brown.edu/cds/projects/iip/viewinscr/caes0080/ (last accessed 10.06.2018).

54 Database Inscriptions of Israel / Palestine "BSHE0016-Scythopolis-Beth Shean, 6th c. CE. Synagogue Mosaic. Dedicatory," http://library.brown.edu/cds/projects/iip/viewinscr/bshe0016/ (last accessed 10.06.2018).

55 Database Inscriptions of Israel / Palestine "ASHK0002-Ashkelon. 604/5 CE. Marble Plaque. Dedication on Synagogue Grate," http://library.brown.edu/cds/projects/iip/viewinscr/ashk0002/ (last accessed 10.06.2018).

56 Cf. Cowley 1915, $211 f$.

57 Cf. Reif 2016, 93-105.

58 Cf. De Lange 1996, 127-154.

59 Cf. De Lange 1996, 43-57. 
This table does not include codices or scrolls of the Greek Bible. It highlights three important aspects: Firstly, it presents plenty of evidence of undoubtful Jewish Greek and Hebrew artefacts containing nomina sacra. This proves that nomina sacra can also be found in Jewish artefacts, dating from the second/third century up to the seventh century for Greek sources (the Genizah material is undated). Consequently, the presence of nomina sacra in artefacts can no longer be regarded as an exclusively Christian scribal feature. Given the vast variety of nomina sacra in other Jewish artefacts, a Jewish origin of Greek Bible manuscripts (codices and scrolls) containing nomina sacra-and so far considered as Christian-can not be excluded.

Possibly Jewish scrolls of the Greek Bible containing nomina sacra include the following three manuscripts: Firstly, P. Oxy 1166 (third century; papyrus; Gen) bears the nomina sacra $\overline{\kappa \varsigma}$ and $\overline{\theta \varsigma}$ (reconstructed). Treu ${ }^{60}$ and $\mathrm{Kraft}^{61}$ speak of a Jewish origin or usage, Roberts and Skeat label it as "possibly so", ${ }^{62}$ Hurtado seems to be undecided ("Jewish?”"63), and Roberts ${ }^{64}$ classifies this scroll as Christian. Kraft regards this manuscript as an

especially important text for the discussion of Jewish and Christian scribal practice [...]. If this text is Jewish in origin, it suggests that the 'biblical majuscule' style may have come into Christianity from Judaism, and that the use of nomina sacra was no less Jewish than Christian in this early period..$^{65}$

Secondly, P. Pisa Lit. 14 (Alexandria, Gr.-Rom. Mus., P. Alex. Inv 203; third/fourth century; papyrus, Isaiah) ${ }^{66}$ presents the nomen sacrum $\overline{\kappa \varsigma}$. A Jewish identification is provided by Kraft, ${ }^{67}$ Hurtado, ${ }^{68}$ and van Haelst, ${ }^{69}$ while Roberts and Skeat regard this manuscript as one of the few Christian Bible scrolls. ${ }^{70}$ Thirdly, P. Oxy. 1075 (London, BL, Inv. 2053v; third/fourth century; papyrus; Exodus) includes the nomen sacrum $\overline{\kappa v}$. Both Treu ${ }^{71}$ and $\mathrm{Kraft}^{72}$ suppose a Jewish provenance.

60 Cf. Treu 1973, 142.

61 Cf. Kraft 2003, 62.

62 Roberts/Skeat 1983, 39.

63 Hurtado 2006, 210.

64 Roberts/Skeat 1983, 39.

65 Kraft 2003, 62.

66 The recto of this manuscript (P. Pisa Lit. 14) has been reused in the third/fourth century as a palimpsest with the text of Rev 1:4-7 (P. Oxy. 1079); cf. Treu 1973, 142: "Was impliziert die christliche Wiederverwendung? Auf den ersten Blick sicher auch christliche Erstherstellung. Aber jüdische Handschriften im Besitz von Christen sind bezeugt.”

67 Cf. Treu 1973, 64.

68 Cf. Hurtado 2006.

69 Cf. van Haelst 1976.

70 Roberts/Skeat 1983, 39.

71 Cf. Kraft 2003, 64.

72 Cf. Kraft 2003, 62f. 
Possibly Jewish Greek Bible codices will be discussed in the next chapter. Deconstructing nomina sacra as being an exclusively Christian marker of a manuscript's identity, has important implications on our understanding of (also possibly Greek mono-lingual) reading practices in ancient synagogues, and highlights the possibly Jewish use of the codex and the ongoing Jewish usage of Greek translations (LXX/ Jewish recensions). These issues will be further discussed in the following parts. In a broader context, this discussion on nomina sacra provides evidence for shared traditions and shared attitudes towards reading Scripture in both ancient Jewish and early Christian communities of reading.

\subsection{The Codex as a Jewish Reading Material}

\subsubsection{From Scroll to Codex}

The development from scroll to codex has often been labelled as a 'media revolution', especially with regard to early Christian communities of reading. In describing this shift, three different approaches can be found in the history of research concerning the underlying actors, driving forces, and communities:

(1) In their monograph Birth of the Codex, Roberts and Skeat assumed with reference to Shaul Lieberman ${ }^{73}$ Rabbinic 'notebooks' as a model for Christian codices, ${ }^{74}$ but their hypothesis did not prevail. ${ }^{75}$ Without referring to Roberts and Skeat or Rabbinic practices, both Treu and $\mathrm{Kraft}^{76}$ emphasise the continuity of early Christian scribal practices with their Jewish heritage and cultural background, especially with regard to the format of the codex.

(2) Most scholars assume a Christian origin or even 'invention' of the codex, while their approaches differ significantly. Reasons for explaining the adoption of the codex are economic ${ }^{77}$ as well as practical. ${ }^{78}$ Some stress an improved portability of codices as advantage for the missionary activities of the early Christian movement, ${ }^{79}$ or assume a conscious decision to use the codex in contrast to ancient Judaism; ${ }^{80}$ others underline the capacity of the codex to contain all the 'canonical' gospels that would not fit on one single scroll, ${ }^{81}$ or, on the contrary, the

73 Cf. Lieberman 1962.

74 Roberts/Skeat 1983, 59f.

75 Cf. Hezser 2001, 433f.

76 Cf. Treu 1973; Kraft 2008.

77 Cf. Cavallo 1999, 84; Harris 1991, 81.

78 Cf. Seeliger 2012, 550f.

79 Cf. Epp 2005, 534; McCormick 1985, 157.

80 Cf. Resnick 1992, 4.

81 Cf. Skeat 2004a, 79: "a codex could contain the texts of all four Gospels. No roll could do this." 
possibility of limiting the 'canonical' texts to the ones contained within the book covers, excluding the possibility of additions. ${ }^{82}$

(3) Bagnall criticises oversimplifying reasoning in characterising the codex as a Christian 'invention', regards the codex as "an artifact of Roman civilisation", and emphasises "how deeply rooted in Roman culture the use of tables was." Tablets have been used by scribes in Egypt, the Ancient Near East, in Archaic and Classical Greece and in ancient Rome. Hence Bagnall sees the codex as an "adaption of the codex of tables" 84 that can be regarded as "another manifestation of what for short we may still call Romanization, the spread of Roman habits and technologies throughout the empire." ${ }^{85}$

\subsubsection{Possible Jewish Greek Bible Codices}

The following chapter discusses possible evidence for Jewish Greek Bible codices and questions their attribution to a Christian origin. If we regard neither the presence of nomina sacra in manuscripts as an exclusively Christian marker of identity, nor the format of the codex as non-Jewish, there is some manuscript evidence of possible Jewish codices dating from the first centuries CE until the Middle Ages. In this regard, the different manuscripts of the Greek Bible/Septuagint have to be studied more comprehensively, but in this paper, I want to discuss only a few codices and argue for both their Jewish origin and usage (see table 2).

The first codices of the Greek Bible (or surviving fragments) date from the second century CE onwards. The first codex to be mentioned here is Oxford, Bodleian Library, Ms. Gr. Bibl. d 5 (P. Oxy. 656; second/third century; papyrus; Gen). While it does not contain any nomen sacrum, the first scribe originally left four blank spaces where the tetragrammaton or forms of its replacement would be expected; in three of these four cases, a second scribe inserted the term kúpıos. Treu, ${ }^{86} \mathrm{Kraft}^{87}$ and Kahle ${ }^{88}$ assume that this codex is Jewish in origin, Roberts writes of a possible Jewish origin, ${ }^{89}$ and Hurtado notes: "Jewish? (Roberts)". ${ }^{90}$ In evaluating this Jewish identification, Stern writes that

82 Cf. Roberts/Skeat 1983.

83 Bagnall 2009, 86; cf. Meyer 2004.

84 Bagnall 2009, 87.

85 Bagnall 2009, 87.

86 Cf. Treu 1973, 142.

87 Cf. Kraft 2003, 61f.

88 Cf. Kahle 1959, 222.

89 Cf. Roberts 1979, 33. 77.

90 Hurtado 2006, 210. 
[...] it is [...] surmised that the original scribe was Jewish. The scribe's identity is especially significant because it is often claimed that early Christianity, no Jews, used the codex as a writing platform for their scriptures, and they did so to distinguish themselves from Jews, who, it is said, exclusively used the scroll as a writing platform. If the scribe of this fragmentary codex was Jewish, it would argue for the opposite reasoning: early Christians may have written in codices not to differentiate themselves from Jews but precisely because the codex was a scribal practice of the Greek-speaking Jewish culture from which Christianity emerged. ${ }^{91}$

P. Oxy. 1007 (London, BL, Inv. Nr. 2047; third century; parchment; Gen) is very likely Jewish in origin. While the tetragrammaton is replaced by two paleo-Hebrew Yodim marked by a horizontal stroke (7z), the term $\theta$ có s is substituted by the nomen sacrum $\overline{\theta c}$. Treu, ${ }^{92} \mathrm{Kraft},{ }^{93}$ and Kahle ${ }^{94}$ attribute this codex to a Jewish origin, while Hurtado remains undecided ("Christian or Jewish?"), ${ }^{95}$ and Roberts presumes Christian origins. ${ }^{96}$

The codex New York, Morgan Library \& Museum, Pap. Gr. 3; P. Amherst 3b (Papyrus 12; third century; papyrus; Gen) dates from the same century and is likely Jewish in origin, too. In contains the nomina sacra $\bar{\theta} \varsigma$ and $\overline{\pi v \alpha}$ and presents both the LXX and the version of Akilas of Gen 1:1-4.5b. However, the actual format of this fragment is

Tab. 2: Possible Jewish Greek Bible Codices

\begin{tabular}{|c|c|c|c|c|}
\hline Dat. & Artefact & Mat. & Content & Nomina Sacra \\
\hline II/III & $\begin{array}{l}\text { Oxford, Bodleian Library, } \\
\text { Ms. Gr. Bibl. d } 5 \text { (P. Oxy- } \\
\text { rhynchus 656) }\end{array}$ & $\mathrm{Pp}$ & $\begin{array}{l}\text { Gen } 14: 21-23 ; 15: 5-9 ; \\
\text { 19:32-20:11; 24:28-47; } \\
27: 32,33,40,41\end{array}$ & $\begin{array}{l}\text { Blank Spaces } \\
\text { (first scribe); } \\
\text { кúpıos (second } \\
\text { scribe) }\end{array}$ \\
\hline III & $\begin{array}{l}\text { London, BL, Inv. Nr. } 2047 \\
\text { (P. Oxyrhynchus 1007) }\end{array}$ & $\mathrm{Pg}$ & $\begin{array}{l}\text { Gen } 2: 7-9,16-19 ; 2: 23-3: 1 \\
3: 6-8\end{array}$ & $77 ; \overline{\theta \varphi}$ \\
\hline III & $\begin{array}{l}\text { New York, Morgan Library } \\
\text { \& Museum, Pap. Gr. 3; P. } \\
\text { Amherst 3b = Papyrus } 12\end{array}$ & $\mathrm{Pp}$ & $\begin{array}{l}\text { Gen } 1: 1-4,5 b(L X X) \\
\text { Gen } 1: 1-2 a .3-4.5 b \text { (Aquila) }\end{array}$ & $\overline{\theta \varsigma}, \overline{\pi v \alpha}$ \\
\hline VI & $\begin{array}{l}\text { Cambridge, Univ. Libr., } \\
\text { T-S } 12.184 \text { and } 20.50\end{array}$ & $\mathrm{Pg}$ & $1 \mathrm{Kgs} 20 ; 2$ Kgs 23 (Aquila) & $\nexists Y \approx 7 ; \overline{K U} ; \overline{1 \sigma \lambda}$ \\
\hline VI & $\begin{array}{l}\text { Cambridge, Univ. Libr., } \\
\text { T-S 12. 186, } 187 \text { and } 188\end{array}$ & $\mathrm{Pg}$ & $\begin{array}{l}\text { Ps 90(89):17-92(91):10; } \\
\text { 96(95):7-12; 98(97):3; } \\
\text { 102(101):16-103(102):13 (Aquila) }\end{array}$ & - \\
\hline
\end{tabular}

91 Stern 2017, 168.

92 Cf. Treu 1973, $141 \mathrm{f}$.

93 Cf. Kraft 2003, 61f.

94 Cf. Kahle 1959, 260.

95 Hurtado 2006, 210.

96 Cf. Roberts 1979. 


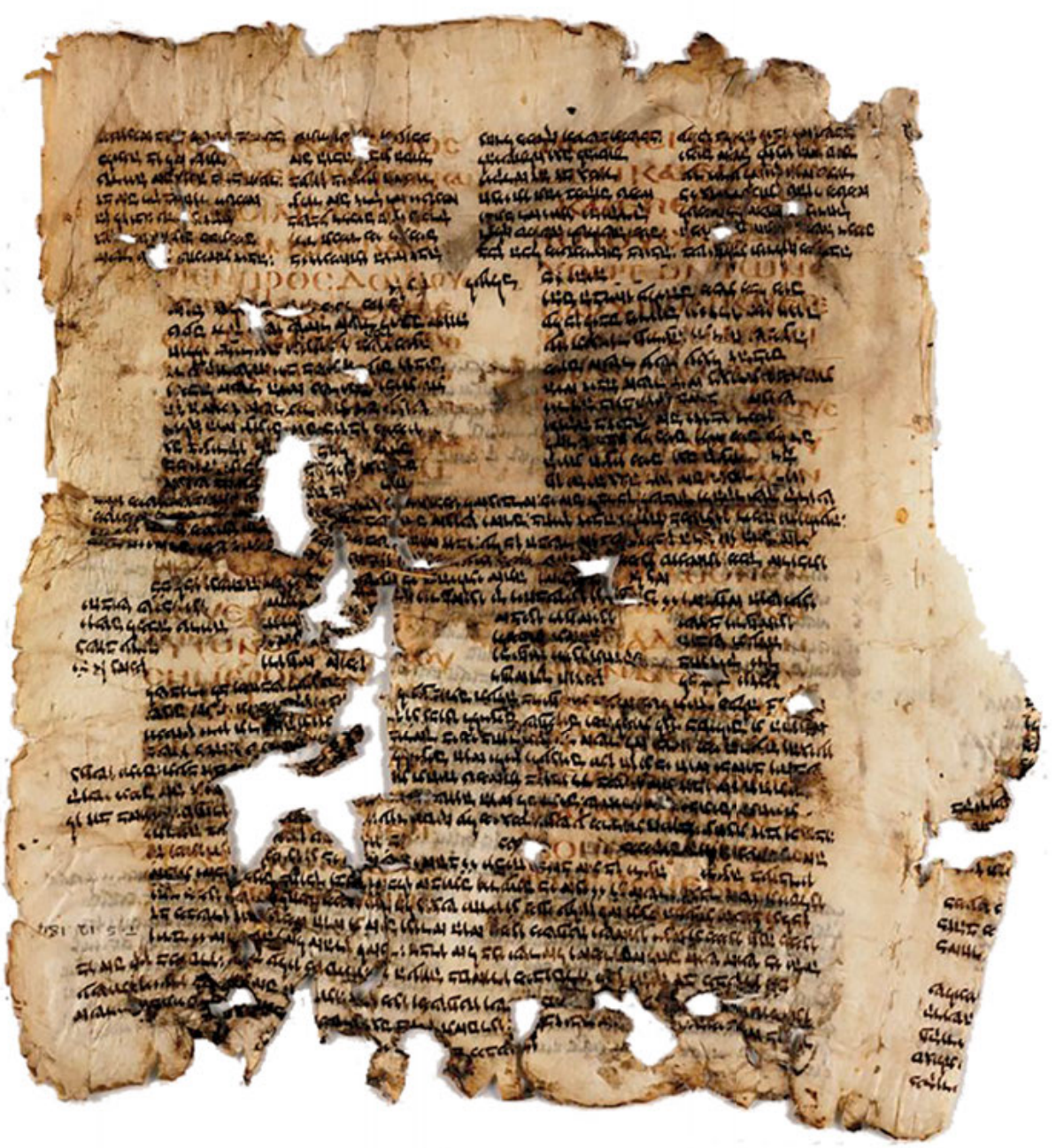

Fig. 1: Cambridge, UL, T-S 12.184.

debated; it may as well be an amulet, a singular sheet, or a fragment of a scroll, ${ }^{97}$ and Roberts assumes Christian origins. ${ }^{98}$

The two Genizah parchment codices Cambridge, Univ. Libr., T-S 12. 184 and 20.50, and Cambridge, Univ. Libr., T-S 12. 186, 187 and 188 date from the sixth century. Both are palimpsests and present the biblical text according to Akilas' translation and in Greek letters. The first consists of two bifolios of a fragment of the book of Kings (3 Kgdms 21; 4 Kgdms 23; MT: 1 Kgs 20; 2 Kgs 23) and its reverse side was reused to write Hebrew Piyyutim of Yannai. ${ }^{99}$ The tetragrammaton is written in paleo-Hebrew

97 Rahlfs/Fraenkel 2004.

98 Roberts 1979, 9.75.76, n. 2.9.

99 Cf. Crawford Burkitt 1897. 
script ( $\approx y \nexists 7)$ with the exception of Greek nomina sacra $(\overline{\kappa v} ; \overline{\imath \sigma \lambda})$ that are used at the end of some lines probably in order to save space. The second codex is a fragment of the Psalms and its reverse side was reused to write verses of the Talmud Yerushalmi (tractate Moed). The tetragrammaton is written in the Psalms-fragment in paleo-Hebrew script and the codex counts verses according to the MT. De Lange describes the script of both codices as "biblical majuscule script" 100 that can usually only be found in Christian manuscripts, but he excludes a Christian origin. ${ }^{101}$ Furthermore he assumes the Jewish synagogal readings as the possible place of reception of both codices:

These large format, carefully written manuscripts, which are free from annotations of any sort, were what we might call 'lectern Bibles', intended to be kept in a synagogue and used for public readings. The use of the Old Hebrew tetragram supports this view [...]. A possible objection to this view is that the books of Kings were not read in their entirety in any synagogue. We do not know enough about synagogal readings to evaluate the force of this objections. ${ }^{102}$

While the presented five examples of codices originate (most likely) from ancient Egypt, their possible Jewish background would have to be contextualised more precisely. With reference to Jewish codices, especially de Lange points to manuscripts and especially Judeo-Greek codices of Byzantine Judaism that are given in the table below: ${ }^{103}$

Tab. 3: Artefacts from Byzantine Judaism.

\begin{tabular}{llll}
\hline Dat. & Artefact & Form/Material & Content \\
\hline V/VI & T-S 12.184. 20.50 & Codex, parchment & $\begin{array}{l}\text { 1 Kgs 20; 2 Kgs 23, Akilas (Egypt/Pales- } \\
\text { tine) }\end{array}$ \\
\hline VI & T-S 12.186. 187. 188 & Codex, parchment & Fragments of Psalms, Akilas (Egypt) \\
\hline XI & T-S Misc. 28.74 & $\begin{array}{l}\text { Single sheet of } \\
\text { parchment }\end{array}$ & Qoh 2:13-23 \\
\hline XIV (?) & Bodleian, Opp. Add. & $\begin{array}{l}\text { Codex, parchment, } \\
\text { 8vo 19 }\end{array}$ & Jonah; Festival Prayers (Romaniote Rite) \\
\hline XV & Bib. Universitaria, & Codex, parchment, & Jonah; Festival Prayers (Romaniote Rite); \\
& MS 3574A & Creta (Candia?)
\end{tabular}

100 De Lange 2015, 79.

101 Cf. De Lange 2015, 80.

102 De Lange 2015, 79.

103 Cf. also Sznol 2012, 218f.

104 Cf. Sznol 2012, 218. 
While the focus of my paper remains in Antiquity, this material heritage of medieval Byzantine Judaism is of crucial importance, since the evidence argues for a tradition of a (possible liturgical) Jewish usage of both the codex and the Greek Bible. De Lange assumes a liturgical usage of the codices given in the table above:

Despite the very fragmentary nature of these materials, I believe they should be considered evidence for the use of actual versions of the Bible, not just ad hoc translations of isolated words and phrases made by teachers and commentators. It is clear that at least some books existed in Greek in the Byzantine synagogue, since we have the Book of Jonah and the fragment of Kohelet. But these are relatively marginal books that had a distinctive liturgical setting. ${ }^{105}$

\subsubsection{The Scroll and the Codex, and the Reader's Experience}

While we already mentioned possible explanations of the shift from scroll to codex, it is also important to examine the impact of these different types of reading material on the reader's experience. In Antiquity, no Jewish or Christian source refers to disadvantages or advantages of either format with regard to the practice of reading, but in studies on the history of reading we often read about the codex as a revolution-in the words of Guglielmo Cavallo: "Above all, the codex dictated a totally different way of reading a text." ${ }^{106}$ Consequently, the practicability of scrolls in comparison to the codex is questioned ("You can imagine how manageable or inconvenient the Pentateuch alone must have been." ${ }^{107}$ ). However, for example Skeat relativises the difficulty of handling a scroll. ${ }^{108}$

Furthermore, it often remains unclear to which kind of reading practice judgements on the practicability of either scrolls or codices refer to. Depending on the type of reading, the material aspects of scrolls and codices influence the reader's experience differently. Therefore, various modes and forms of reading have to be differentiated:

105 De Lange 2012, 376f.; emph. in original.

106 Cavallo 1999, 88.

107 Wallraff 2013, 9 ("Man kann sich vorstellen, wie handlich bzw. unhandlich allein der Pentateuch gewesen sein muss.”).

108 Cf. Skeat 2004b: "Many writers on the use of manuscripts in the ancient world have emphasised the difficulty experienced by the reader of a papyrus roll when he came to the end of the roll and was faced by the necessity to re-roll it for the benefit of the next reader; and it has often been claimed that this re-rolling was a troublesome and lengthy process. [...] So far as I know, this suggestion has never been put to a practical test, and my own experience may therefore be of some interest." (60f.) He continues: "I conclude therefore that re-rolling a papyrus roll presented no great difficulty to a reader, especially in an age when there was no demand for labour-saving devices. And the necessity for re-rolling is unlikely to have been an important factor in the long drawn-out battle between the roll and the codex. Those who stress the advantage of the codex form in this regard must in any case explain the existence of hundreds of thousands of rolls which have survived from the Middle Ages and even later; but this is another and larger question, too long to be debated here.” (62f.) 
Forms of reading include liturgical reading/recitation in the synagogue, reading as memory aid, and private textual study, while modes of reading include continuous reading or lectio continua, exegetical, private reading, and reading for information. In addition, the usage of scroll and codex should be evaluated more precisely in relation to other criteria, such as textual or meta-textual divisions, pagination, as well as, in general, the content of each format. Thus, the different reading experiences of either scroll or codex should be examined according to following criteria:

(1) panoramic or fragmented reading: The perception of text at the micro- or macroscale;

(2) liturgical, exegetical, private reading, or reading for information;

(3) physical features: size and format; luxury or miniature editions; acts of 'scrolling'/unfolding a scroll, and leafing through a codex;

(4) inclusion of reading aids, like page numbers, divisions, and paragraphs;

(5) inclusion of meta-texts, like commentaries or glosses;

(6) content: Single works, or inclusion of several books in one volume/manuscript;

(7) impacts of an oral mnemonic culture on the reading materials and vice versa.

With regard to the "history of textuality", Eva Mroczek warns against "linear, supercessionist, and materially determinist" ${ }^{109}$ views and against "dangers of naturalizing certain modes of text production and reading as inherent to particular materialities."110

\subsection{Continuity of a Jewish Usage of the Greek as a 'Holy Language'}

The Jewish Greek translation of the scriptures that would later form the Jewish Bible is one of the most important elements of the rich legacy of Hellenistic Judaism. However, the thesis of a Jewish 'rejection' of the Greek Bible can be found equally in Christian and Jewish discourses. ${ }^{111}$ Less or more implicitly, the Septuagint appears to become a 'baptized' Greek Christian Bible, losing its Jewish roots and identity. This point of view marginalises the Jewish heirs of Hellenistic Judaism in Antiquity and late Antiquity, runs risk of perpetuating Christian theologies of substitution, reduces the LXX and Jewish Greek Bible versions to a praeparatio evangelica, and promotes a development that would be unique in the history of religion: a religious community giving up its very own and sacred text when facing the development and consolidation of another religious community. The thesis of the Jewish 'rejection' of the LXX/ Greek Bible implies moreover the danger of uncritically perpetuating orthodox discourses, either on the Christian patristic or on the Rabbinic side, and of misinterpreting them as reflecting a historical reality. Similarly, Daniel Boyarin refers to precisely

109 Mroczek 2011, 243.

110 Mroczek 2011; emph. in original.

111 Cf. the summaries given by De Lange 2015; Veltri 1994, 2006. 
those moments and processes of competing orthodoxies that brought forth Christianity and Judaism as separated entities. ${ }^{112}$

Theories on an assumed Jewish rejection of the Greek Bible are according to Thessa Rajak "largely constructed on the platform of a handful of specific statements taken out of a patristic or a rabbinic context". ${ }^{113}$ Giuseppe Veltri describes the patristic construction of a Jewish rejection as "pure Christian propaganda"114 and de Lange regards the thesis of the Jewish rejection of its Greek literary heritage as a form of Christian 'replacement' theology:

'Replacement' theology has influenced attitudes to the Septuagint in various ways. Its impact is mostly felt in exegesis, but it can also affect the writing of history, as when Christian authors claim that soon after the arrival of Christianity the Septuagint was 'transferred from the hands of the Jews to the Christian Church. ${ }^{115}$

Thus, especially de Lange's studies re-evaluate the Jewish Greek heritage and argue for an unbroken chain of tradition, reception and usage of the Greek Bible in Jewish communities from Antiquity, to the Middle Ages and beyond, especially in Byzantine Judaism:

No Jewish source refers unambiguously to the use of Greek biblical versions by Jews in Byzantium, and we have no Jewish manuscripts of the entire Bible in Greek, or even of the Pentateuch. We do, however, have some continuous texts in manuscripts, as well as a printed version of the Pentateuch [...]. The absence of more extensive manuscripts does not necessarily mean that these never existed: we should bear in mind the enormous losses of manuscripts in Byzantium. It is clear from booklists and stray leaves of otherwise unknown works that many texts, even ones that were once quite widely distributed, have disappeared. ${ }^{116}$

This continuity can be proved by different Jewish Greek Bible codices, scrolls, amulets, Bible commentaries, glossaries, scholia, and epigraphic evidence. ${ }^{117}$ This unbroken tradition includes also the usage of Greek Bible codices in synagogal readings and possible monolingual regular readings of Torah in the first centuries CE. Concerning the language of the Torah reading, the Rabbinic preference for Hebrew as the only 'holy language' and for Aramaic as the Targum's translation should not always be taken historically: hence, there might have been more than the Rabbinic normative Hebrew-Aramaic reading, for example possible monolingual Greek, and in a later development of ancient Judaism a possible Hebrew-Greek bilingual reading: "Those scholars who still maintain a relatively monolithic view of synagogal practice in Late

112 Cf. Boyarin 2007.

113 Rajak 2009, 297.

114 Veltri 2006, 104.

115 De Lange 2013, 147.

116 De Lange 2010, 45.

117 Cf. esp. De Lange 1996, 2015. 
Antiquity in which Hebrew recitation is held to be the norm, must project the rabbinic ideal onto the whole Diaspora."118

A Greek monolingual synagogal reading ${ }^{119}$ may have been the standard not only in the ancient Jewish diaspora but also in some parts of Jewish Palestine in the first century CE when Greek became the Jewish lingua franca: ${ }^{120}$ " [...] for large numbers of Jews it was also the language in which they were educated, the only language they could read and write, and the language of their religious culture." ${ }^{21}$ Hence, independently of questions on the origins of the Septuagint in Hellenistic Judaism, in the context of the monolingual reading the Greek Bible assumes a liturgical function. Only later and following an increasing hebraisation, the Hebrew-Aramaic bilingual reading appeared. ${ }^{122}$

In an assumed monolingual Greek synagogal reading of the Bible the translation is more than just Targum: In contrast, the Greek Bible becomes holy in itself, thus representing not only a translation of the Hebrew 'original', but replacing it. To what extent the above mentioned possible Jewish codices of the Greek Bible may be considered as being part of this Greek Jewish tradition of reading needs to be examined in greater detail, also with regard to the relation between oral-mnemonic reading and reading from written manuscripts. However, the continuity of the Jewish-Greek tradition cannot be emphasised enough; also the epigraphic evidence speaks for a prevalence of the Greek in Jewish communities both in Palestine and the diaspora. ${ }^{123}$ With regard to the question when and why the monolingual Greek reading evolved to a Hebrew-Aramaic, scholarship is divided: While Smelik assumes both a Rabbinic "regularisation of public translation" in the context of the Usha-period (second century $\mathrm{CE}$ ) and a Hebrew-Aramaic bilingual reading after the Bar Kokhba revolt (mid-second century CE) in Jewish Palestine and in the Babylonian diaspora, ${ }^{124}$ de Lange dates the process of hebraisation to the tenth century:

It is clear from epigraphical and other sources that in late antiquity the normal language of Jewish worship in Egypt, Asia Minor, and Europa was Greek. It is equally clear that by the tenth century Hebrew had replaced Greek for this purpose, and that public readings from the Bible throughout the Jewish world were conducted in Hebrew. We do not know when or why or how the Hebrew Bible acquired its preeminent position, but an interesting clue is provided by a decree of emperor Justinian I dated 8 February 553, which depicts a Jewish community seriously divided on this issue. ${ }^{125}$

118 Smelik 2013, 187.

119 Cf. De Lange 2015, 55-60; Smelik 2007, 141; Smelik 2013, 185; Van der Horst 2014, 228; Rajak 2009, 143-152; Edrei/Mendels 2007, 95-101; Lieberman 1942, 59.

120 Cf. Van der Horst 2001.

121 De Lange 2015, 39.

122 Cf. Smelik 2007.

123 Cf. Van der Horst 2014, 228; Smelik 2013, 189.

124 Cf. Smelik 2007, 147.

125 De Lange 2010, 42f. 


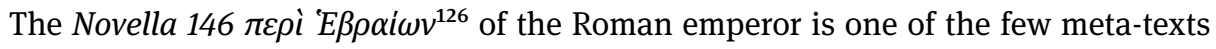
describing Jewish Greek traditions of reading in ancient synagogues; however, both impact and scope of this decree remain controversial with regard to the influences on historical Jewish reading practices. Novella 146 consists of a prologue mentioning an inner-Jewish conflict about the language of the liturgical readings as justifying the emperor's jurisdiction, three chapters, and an epilogue. In the first chapter Justinian permits the admission of the Greek language while recommending the usage of the Septuagint but also approving Akilas translation. In the same chapter, he furthermore bans $\delta \varepsilon v \tau \varepsilon \dot{\rho} \omega \sigma \iota \varsigma$ (Deuterosis) ${ }^{127}$ as human invention and 'worthless and vain phrases'. Already Zunz wrote in 1892: “Justinians bekannte Novelle verbreitet mehr Dunkelheit als Licht über diesen Gegenstand [...]." ${ }^{128}$ Thus, the Novella's interpretation and impact are discussed differently: while Kahle speaks of Greek-speaking Jews as demanding a bilingual Hebrew-Greek reading instead of a monolingual Hebrew practice, ${ }^{129}$ de Lange interprets the Novella as evidence for a confrontation between the defenders of the Greek traditions and their opponents trying to establish a Hebrew reading practice. ${ }^{130}$ Similarly, Smelik regards the Novella as a "turning point in reading practices"131 that turns against the Greek readings and advocates for the Hebrew language. In Veltri's interpretation, the mentioned inner-Jewish conflict is only an excuse for the emperor to justify his theological and political programme aiming at converting the Jews. ${ }^{132}$ Furthermore, Stemberger warns that there is no clear evidence of any impact of the Novella on Jewish liturgy and reading practices. ${ }^{133}$

\section{Conclusions}

The importance of examining more closely the Greek evidences of ancient Judaism for the study of ancient Jewish reading practices has been shown in this paper. While neither a wide distribution of biblical manuscripts nor public and regular readings of Torah can be taken for granted in antiquity, Judaism develops into a 'religion of the book' only in the first centuries CE, a time when both synagogal monolingual Greek reading practices and Greek Bible codices appeared. It is argued that the format of the codex can be understood as an important feature of Greek Jewish literary heritage.

126 Cf. the translation by Kahle 1959, 315-317.

127 The meaning of $\delta \varepsilon v \tau \varepsilon \dot{\rho} \omega \sigma \mathrm{s}$ is debated and often interpreted as Greek translation of Mishnah, designating Oral Torah.

128 Zunz 1892, 11.

129 Kahle 1959, 39-41.

130 Cf. De Lange 2006, 171; De Lange 2016; 2015, 60-67.

131 Smelik 2013, 188.

132 Veltri 2002, 105.

133 Cf. Stemberger 2012a, 137. 
Questioning the format of the codex and the presence of nomina sacra as exclusively Christian markers of identity blurs the boundaries between Jewish and Christian scribal and reading cultures. The results of this paper have important implications on the understanding of reading practices in ancient synagogues, and highlight the Jewish use of the codex and the ongoing usage of Greek translations in Jewish communities.

In a broader context, the results deliver evidence for shared traditions and reading practices in both ancient Jewish and early Christian communities: the evidence for the early centuries CE argues rather for unparted ways than for clear-cut parted traditions, with regard to reading practices (language, usage in context, shared traditions), literatures (Greek Bible), and material aspects (codex).

\section{Bibliography}

Ameling, Walter (ed.) (2004), Inscriptiones Judaicae Orientis, Band II: Kleinasien, Tübingen. Assmann, Jan (2010), The Price of Monotheism, Stanford.

Bagnall, Roger S. (2009), Early Christian Books in Egypt, Princeton/Woodstock.

Baumgarten, Albert I. (1985), "The Torah as a Public Document in Judaism”, in: SR 14, 17-24.

Becker, Adam H./Reed, Annette Yoshiko (eds.) (2003), The Ways that Never Parted. Jews and Christians in Late Antiquity and the Early Middle Ages, Tübingen.

Benovitz, Nancy (2016), "Psalm 91:1 and the Rabbinic Shema' in Greek on a Byzantine Amuletic Armband", in: Textus 26, 143-171.

Boyarin, Daniel (2003), “Placing Reading. Ancient Reading and Medieval Europe”, in: Daniel Boyarin, Sparks of the Logos. Essays in Rabbinic Hermeneutics (Brill Reference Library of Judaism 11), Leiden/Boston, 59-88.

Boyarin, Daniel (2007), Border Lines: The Partition of Judaeo-Christianity (Divinations), Philadelphia, $\mathrm{Pa}$.

Brea, Bernabò Luigi (1965), Akrai (Monografie Archeologiche della Sicilia 1), Catania.

Brown, Schuyler (1970), “Concerning the Origin of the Nomina Sacra”, in: Studia Papyrologica 9 , 7-19.

Carr, David (2005), Writing on the Tablet of the Heart. Origins of Scripture and Literature, Oxford.

Cavallo, Guglielmo (1999), "Between Volumen and Codex: Reading in the Roman World", in Guglielmo Cavallo and Roger Chartier (eds.), A History of Reading in the West, Amherst, 64-89.

Cohen, Abraham (ed.) (1956a), The Minor Tractates of the Talmud in Two Volumes, Vol. I, London.

Cohen, Abraham (ed.) (1956b), The Minor Tractates of the Talmud in Two Volumes, Vol. II, London.

Cowley, Arthur Ernest (1915), “Notes on Hebrew Papyrus Fragments from Oxyrhynchus”, in: Journal of Egyptian Archeology 2, 209-213.

Crawford Burkitt, Francis (1897), Fragments of the Books of Kings according to the Translation of Aquila. From a MS formerly in the Geniza at Cairo, now in the Possession of C. Taylor

D. D. Master of S. John's College and S. Schechter M. A. University Reader in Talmudic Literature, Cambridge.

De Lange, Nicholas (1996), Greek Jewish Texts from the Cairo Genizah (Texte und Studien zum antiken Judentum 51), Tübingen. 
De Lange, Nicholas (2006), “Can we speak of Jewish Orthodoxy in Byzantium?”, in: Andrew Louth and Augustine Casiday (eds.), Byzantine Orthodoxies. Papers from the Thirty-Sixth Spring Symposium of Byzantine Studies, University of Durham, 23-25 March 2002 (Society for the Promotion of Byzantine Studies Publications 12), Aldershot, 167-178.

De Lange, Nicholas (2010), “The Greek Bible Translations of the Byzantine Jews”, in: Paul Magdalino and Robert Nelson (eds.), The Old Testament in Byzantium, Washington, 39-54.

De Lange, Nicholas (2012), “The Greek Bible in the Medieval Synagogue”, in: Robert Bonfil et al. (eds.), Jews in Byzantium. Dialectics of Minority and Majority Cultures (Jerusalem Studies in Religion and Culture 14), Leiden/Boston, 371-384.

De Lange, Nicholas (2013), “The Septuagint as a Jewish Classic”, in: Sarah C. Humphreys and Rudolf G. Wagner (eds.), Modernity's Classics (Transcultural Research-Heidelberg Studies on Asia and Europe in a Global Context), Berlin/Heidelberg, 143-165.

De Lange, Nicholas (2015), Japheth in the Tents of Shem. Greek Bible Translations in Byzantine Judaism (Texts and Studies in Medieval and Early Modern Judaism 30), Tübingen.

De Lange, Nicholas (2016), “Hebraists and Hellenists in the Sixth-Century Synagogue: A New Reading of Justinian's Novel 146", in: Constanza Cordoni and Gerhard Langer (eds.), 'Let the Wise Listen and add to Their Learning' (Prov 1:5): Festschrift for Günter Stemberger on the Occasion of his 75th Birthday (Studia Judaica 90), Berlin/Boston, 217-226.

Edrei, Arye/Mendels, Doron (2007), “A Split Jewish Diaspora: Its Dramatic Consequence”, in: Journal for the Study of Pseudepigrapha 16, 91-137.

Edwards, James R. (2009), “A Nomen Sacrum in the Sardis Synagogue”, in: Journal of Biblical Literature 128, 813-821.

Epp, Eldon Jay (2005), “The Codex and Literacy in Early Christianity and at Oxyrhynchus: Issues Raised by Harry Y. Gamble's Books and Readers in the Early Church”, in: Eldon Jay Epp, Perspectives on New Testament Textual Criticism. Collected Essays, 1962-2004 (Supplements to Novum Testamentum 116), Leiden/Boston 521-550.

Frey, Jean-Baptiste (ed.) (1936), Corpus Inscriptionum Iudaicarum: Recueil des inscriptions juives qui vont du Ille siècle avant, vol 1: Europe, Rom.

Gamble, Harry Y. (1995), Books and Readers in the Early Church. A History of Early Christian Texts, New Haven/London.

Gelardini, Gabriella (2007), “Verhärtet eure Herzen nicht”. Der Hebräer, eine Synagogenhomilie zu Tischa be-Aw (Biblical Interpretation Series 83), Leiden et al.

Goodblatt, David M. (2006), Elements of Ancient Jewish Nationalism, Cambridge et al.

Hachlili, Rachel (2013), Ancient Synagogues - Archaeology and Art. New Discoveries and Current Research (Handbook of Oriental Studies I 105), Leiden/Boston.

Harris, William V. (1991), “Why did the Codex Supplant the Book-Roll?”, in: John Monfasani and Ronald G. Musto (eds.), Renaissance Society and Culture. Essays in Honour of E. F. Rice jr, New York, 71-85.

Hezser, Catherine (2001), Jewish Literacy in Roman Palestine (Texts and Studies in Ancient Judaism 81), Tübingen.

Hezser, Catherine (2003), “Jewish Literacy and the Use of Writing in Late Roman Palestine”, in: Richard Kalmin and Seth Schwartz (eds.), Jewish Culture and Society Under the Christian Roman Empire, Leiden/New York, 149-195.

Hezser, Catherine (ed.) (2010), The Oxford Handbook of Jewish Daily Life in Roman Palestine, Oxford et al.

Hilgert, Markus (2010), “'Text-Anthropologie’: Die Erforschung von Materialität und Präsenz des Geschriebenen als hermeneutische Strategie", in: Markus Hilgert (ed.), Altorientalistik im 21. Jahrhundert. Selbstverständnis, Herausforderungen, Ziele (Mitteilungen der Deutschen Orient-Gesellschaft 142), 87-126. 
Himmelfarb, Martha (2013), "The Torah between Athens and Jerusalem: Jewish Difference in Antiquity", in: Martha Himmelfarb, Between Temple and Torah: Essays on Priests, Scribes, and Visionaries in the Second Temple Period and beyond (Texts and Studies in Ancient Judaism 151), Tübingen, 221-234.

Horbury, William/Noy, David (eds.) (1992), Jewish Inscriptions of Graeco-Roman Egypt, New York/ Cambridge.

Howard, George (1977), “The Tetragram and the New Testament”, in: Journal of Biblical Literature 96, 63-83.

Hurtado, Larry W. (1998), “The Origin of the Nomina Sacra: A Proposal”, in: Journal of Biblical Literature 117, 655-673.

Hurtado, Larry W. (2000), “The Earliest Evidence of an Emerging Christian Material and Visual Culture: The Codex, the Nomina Sacra and the Staurogram", in: Michel Robert Desjardins and Stephen G. Wilson (eds.), Text and Artifact in the Religions of Mediterranean Antiquity. Essays in Honour of Peter Richardson (Studies in Christianity and Judaism 9), Waterloo, 271-288.

Hurtado, Larry W. (2006), The Earliest Christian Artifacts. Manuscripts and Christian Origins, Grand Rapids.

Hurtado, Larry W. (2012), “Manuscripts and the Sociology of Early Christian Reading”, in: Charles E. Hill and Michael J. Kruger (eds.), The Early Text of the New Testament, Oxford, 49-62.

Hurtado, Larry W. (2010), Nomina Sacra: The Continuing Debate <https://larryhurtado.wordpress. com/2010/09/22/nomina-sacra-the-continuing-debate/> (last accessed 10.06.2018).

Japhet, Sara (2015), “The Ritual of Reading Scripture (Nehemiah 8:1-12)”, in: Hans M. Barstad et al. (eds.), New Perspectives on Old Testament Prophecy and History. Essays in Honour of Hans M. Barstad (Supplements to Vetus Testamentum 168), Leiden/Boston, 175-190.

Johnson, William A. (2000), "Toward a Sociology of Reading in Classical Antiquity”, in: American Journal of Philology 12, 593-627.

Kahle, Paul (1959), The Cairo Geniza, Oxford.

Klein-Franke, Felix (1983), “A Hebrew Lamentation from Roman Egypt”, in: Zeitschrift für Papyrologie und Epigraphik 51, 80-84.

Kotansky, Roy (1994), Greek Magical Amulets: The Inscribed Gold, Silver, Copper, and Bronze Lamellae. Part I: Published Texts of Known Provenance (Abhandlungen der Rheinisch-Westfalischen Akademie der Wissenschaften Sonderreihe Papyrologica Coloniensia 22), Wiesbaden.

Kraft, Robert A. (2002), Early Jewish and Christian Scriptural Artifacts: Continuities, Discontinuities, and Social Significance <http://ccat.sas.upenn.edu/rak//earlylxx/sbl2002.htm> (last accessed 10.06.2018).

Kraft, Robert A. (2003), “The 'Textual Mechanics' of Early Jewish LXX/OG Papyri and Fragments”, in: Scot McKendrick and Orlaith A. O'Sullivan (eds.), The Bible as Book. The Transmission of the Greek Text, London/Grand Haven, 51-72.

Kraft, Robert A. (2008), Files and Information on Early Jewish and Early Christian Copies of Greek Jewish Scriptures <http://ccat.sas.upenn.edu/rak//earlylxx/jewishpap.html> (last accessed 10.06.2018).

Kroll, John H. (2001), “The Greek Inscriptions of the Sardis Synagogue”, in: Harvard Theological Review 91, 5-55.

Levine, Lee I. (ed.) (1987), The Synagogue in Late Antiquity, Philadelphia.

Levine, Lee I. (2005), The Ancient Synagogue. The First Thousand Years, New Haven et al.

Lieberman, Saul (1942), "The Greek of the Synagogue”, in: Saul Lieberman, Greek in Jewish Palestine. Studies in the Life and Manners of Jewish Palestine in the II-IV Centuries C. E, New York, 29-67. 
Lieberman, Saul (1962), Hellenism in Jewish Palestine. Studies in the Literary Transmission. Beliefs and Manners of Palestine in the I century B.C.E.-IV century C.E. (Texts and Studies of the Jewish Theological Seminary of America 18), New York.

Llewelyn, Stephen R. (ed.) (1998), New Documents Illustrating Early Christianity. A Review of the Greek Inscriptions and Papyri Published in 1984-85, North Ryde/Grand Rapids.

Mccormick, Michael (1985), “The Birth of the Codex and the Apostolic Life-Style”, in: Scriptorium 39, 150-158.

Meyer, Elizabeth A. (2004), Legitimacy and Law in the Roman World. Tabulae in Roman Belief and Practice, Cambridge et al.

Mosser, Carl (2012), “Torah Instruction, Discussion, and Prophecy in First-Century Synagogues”, in: Stanley E. Porter and Andrew W. Pitts (eds.), Christian Origins and Hellenistic Judaism. Social and Literary Contexts for the New Testament (Texts and Editions for New Testament Study 10), Leiden, 523-551.

Mroczek, Eva (2011), “Thinking Digitally about the Dead Sea Scrolls: Book History before and beyond the Book", in: Book History 14, 241-269.

Noy, David/Panayotov, Alexander/Bloedhorn, Hanswulf (eds.) (2004), Inscriptiones Judaicae Orientis, vol 1: Eastern Europe, Tübingen.

Paap, Anton H. (1959), Nomina Sacra in the Greek Papyri of the First Five Centuries A.D. The Sources and Some Deductions (Papyrologica Lugduno-Batava 8), Leiden.

Perrot, Charles (1990), “The Reading of the Bible in the Ancient Synagogue”, in: Martin Jan Mulder and Harry Sysling (eds.), Mikra. Text, Translation, Reading and Interpretation of the Hebrew Bible in Ancient Judaism and Early Christianity (Compendia Rerum ludaicarum ad Novum Testamentum: The Literature of the Jewish People in the Period of the Second Temple and the Talmud II 1), Assen/Minneapolis, 137-159.

Pietsch, Michael (2011), “'Ich habe das Gesetzbuch gefunden im Haus des HERRN.' Anfänge der Buchreligion im Alten Israel?", in: Maike Schult and Philipp David (eds.), Wortwelten. Theologische Erkundung der Literatur, Berlin, 143-168.

Rahlfs, Alfred/Fraenkel, Detlef (2004), Die Überlieferung bis zum VIII. Jahrhundert (Septuaginta Verzeichnis der griechischen Handschriften des Alten Testaments I, 1), Göttingen.

Rajak, Tessa (2009), Translation and Survival. The Greek Bible of the Ancient Jewish Diaspora, Oxford/New York.

Reif, Stefan C. (2016), Jewish Prayer Texts from the Cairo Genizah. A Selection of Manuscripts at Cambridge University Library (Études sur le Judaïsme Médiéval 66/Cambridge Genizah Studies Series 7), Leiden/Boston.

Resnick, Irven M. (1992), “The Codex in Early Jewish and Christian Communities”, in: Journal of Religious History 17, 1-17.

Roberts, Colin H. (1979), Manuscript, Society and Belief in Early Christian Egypt (The Schweich Lectures of the British Academy), London.

Roberts, Colin H./Skeat, Theodore C. (1983), The Birth of the Codex, London/New York.

Runesson, Anders (2001), The Origins of the Synagogue. A Socio-Historical Study (Coniectanea Biblica 37), Stockholm.

Satlow, Michael L (2014), How the Bible Became Holy, New Haven.

Schaper, Joachim (2007), “Tora als Text im Deuteronomium”, in: Ludwig Morenz and Stefan Schorch (eds.), Was ist ein Text? Alttestamentlich, ägyptologische und altorientalistische Perspektiven (Beihefte zur Zeitschrift für die alttestamentliche Wissenschaft 362), Berlin et al., 49-63.

Scharbach Wollenberg, Rebecca (2015), The People of the Book without the Book. Jewish Ambivalence towards Biblical Text after the Rise of Christianity, PhD Diss. University of Chicago: Divinity School. 
Schiffman, Lawrence H. (1999), “The Early History of Public Reading of the Torah”, in: Steven Fine (ed.), Jews, Christians, and Polytheists in the Ancient Synagogue. Cultural Interaction during the Greco-Roman Period, New York, 38-49.

Schmid, Konrad (2012), "The Canon and the Cult: The Emergence of Book Religion in Ancient Israel and the Gradual Sublimation of the Temple Cult", in: Journal of Biblical Literature 131, 289-305.

Schorch, Stefan (2004), Die Vokale des Gesetzes. Die samaritanische Lesetradition als Textzeugin der Tora, vol 1: Das Buch Genesis, Berlin/Boston.

Schorch, Stefan (2007), "The Libraries in 2 Macc 2:13-15, and the Torah as a Public Document in Second Century BC Judaism”, in: Géza G. Xeravits and József Zsengellér (eds.), The Books of the Maccabees: History, Theology, Ideology. Papers of the Second International Conference on the Deuteronomical Books, Pápa, Hungary, 9-11 June, 2005 (Supplements to the Journal for the Study of Judaism 118), Leiden/Boston, 169-180.

Schorch, Stefan (2009a), "Sakralität und Öffentlichkeit: Bibelübersetzungen als Paradigmen jüdischen Übersetzens”, in: Eva Lezzi and Dorothea Salzer (eds.), Dialog der Disziplinen: Jüdische Studien und Literaturwissenschaft (Minima Judaica 6), Berlin, 51-76.

Schorch, Stefan (2009b), “Communio Lectorum: Die Rolle des Lesens für die Textualisierung der israelitischen Religion”, in: Joachim Schaper (ed.), Die Textualisierung der Religion (Forschungen zum Alten Testament 62), Tübingen, 167-184.

Schremer, Adiel (2001), “'[T]he[y] Did Not Read in the Sealed Book': Qumran Halakhic Revolution and the Emergence of Torah Study in Second Temple Judaism", in: David Goodblatt et al. (eds.), Historical Perspectives: From the Maccabees to Bar Kokhba in Light of the Dead Sea Scrolls. Proceedings of the Fourth International Symposium of the Orion Center for the Study of the Dead Sea Scrolls and Associated Literature, 27-31 January, 1999 (Studies on the Texts of the Desert of Judah 37), Leiden et al., 105-126.

Schwartz, Seth (2001), Imperialism and Jewish Society, 200 B.C.E. to 640 C.E. (Jews, Christians, and Muslims from the Ancient to the Modern World), Princeton.

Seeliger, Hans Reinhard (2012), "Buchrolle, Codex, Kanon. Sachhistorische und ikonographische Aspekte und Zusammenhänge”, in: Eva-Marie Becker and Stefan Scholz (eds.), Kanon in Konstruktion und Dekonstruktion. Kanonisierungsprozesse religiöser Texte von der Antike bis zur Gegenwart, Berlin/Boston, 547-576.

Shinan, Avigdor (1987), "Sermons, Targums, and the Reading from Scriptures in the Ancient Synagogue”, in: Lee I. Levine (ed.), The Synagogue in Late Antiquity, Philadelphia, 97-110.

Sirat, Colette (1985), Les papyrus en caractères hébraïques trouvés en Égypte (Manuscrits médiévaux en caractères hébraïques), Paris.

Skeat, Theodore C. (1969), "Early Christian Book-Production: Papyri and Manuscripts", in: G. W. H. Lampe (ed.), The Cambridge History of the Bible, Bd.2: The West from the Fathers to the Reformation, Cambridge et al., 54-79.

Skeat, Theodore C. (2004a), “The Origin of the Christian Codex”, in: James Keith Elliott (ed.), The Collected Biblical Writings of T. C. Skeat (Supplements to Novum Testamentum 113), Leiden/ Boston, 79-87.

Skeat, Theodore C. (2004b), "Two Notes on Papyrus: I. Was Re-Rolling a Papyrus Roll an Irksome and Time-consuming Task? II. Last Words on the Question: Was an Adhesive Used in the Manufacture of Papyrus?", in: James Keith Elliott (ed.), The Collected Biblical Writings of T. C. Skeat (Supplements to Novum Testamentum 113), Leiden/Boston, 60-64.

Skeat, Theodore C. (2004c), "Early Christian Book-Production: Papyri and Manuscripts", in James Keith Elliott (ed.), The Collected Biblical Writings of T. C. Skeat (Supplements to Novum Testamentum 113), Leiden/Boston, 33-59. 
Smelik, Willem F. (2007), "Code-switching: The Public Reading of the Bible in Hebrew, Aramaic and Greek”, in: Ludwig Morenz and Stefan Schorch (eds.), Was ist ein Text? Alttestamentliche, ägyptologische und altorientalische Perspektiven (Beihefte zur Zeitschrift für die alttestamentliche Wissenschaft 362), Berlin/New York, 123-151.

Smelik, Willem F. (2013), Rabbis, Language and Translation in Late Antiquity, Cambridge.

Stemberger, Günter (2012a), Judaica Minora II: Geschichte und Literatur des rabbinischen Judentums (Texts and Studies in Ancient Judaism 138), Tübingen.

Stemberger, Günter (2012b), “Öffentlichkeit der Tora im Judentum - Anspruch und Wirklichkeit”, in Günter Stemberger, Judaica Minora I: Biblische Traditionen im rabbinischen Judentum (Texts and Studies in Ancient Judaism 133), Tübingen, 27-37.

Stern, David (2008), “The First Jewish Book and the Early History of Jewish Reading”, in: Jewish Quarterly Review 98, 163-202.

Stern, David (2017), The Jewish Bible: A Material History (Samuel and Althea Stroum Lectures in Jewish Studies), Seattle/Washington.

Sznol, Shifra (2012), “Text and Glossary: Between Written Text and Oral Tradition”, in: Timothy Michael Law and Alison Salvesen (eds.), Greek Scripture and the Rabbis (Contributions to Biblical Exegesis an Theology 66), Leuven et al., 217-232.

Traube, Ludwig (1907), Nomina Sacra: Versuch einer Geschichte der christlichen Kürzung, München.

Treu, Kurt (1973), “Die Bedeutung des Griechischen für die Juden im Römischen Reich”, in: Kairos 15, 123-144.

Turner, Eric G. (1977), The Typology of the Early Codex (Haney Foundation Series 18), Philadelphia.

Van der Horst, Pieter Willem (2001), “Greek in Jewish Palestine in Light of Jewish Epigraphy”, in: John J. Collins and Gregory E. Sterling (eds.), Hellenism in the Land of Israel (Christianity and Judaism in Antiquity 13), Notre Dame, 154-174.

Van der Horst, Pieter Willem (2014), “Jewish-Greek Epigraphy in Antiquity”, in: James K. Aitken and James Carleton Paget (eds.), The Jewish-Greek Tradition in Antiquity and the Byzantine Empire, New York, 215-228.

Van Haelst, Joseph (1976), Catalogue des papyrus littéraires juifs et chrétiens (Publications de la Sorbonne, Série Papyrologie 1), Paris.

Van Haelst, Joseph (1989), “Les origines du Codex”, in: Alain Blanchard (ed.) Les Débuts Du Codex (Bibliologia Elementa ad Librorum Studia Pertinentia 9), Turnhout, 13-35.

Veltri, Giuseppe (1994), Eine Tora für den König Talmai: Untersuchungen zum Übersetzungsverständnis in der jüdisch-hellenistischen und rabbinischen Literatur (Texts and Studies in Ancient Judaism 41), Tübingen.

Veltri, Giuseppe (2002), Gegenwart der Tradition: Studien zur jüdischen Literatur und Kulturgeschichte (Supplements to the Journal for the Study of Judaism 69), Leiden et al.

Veltri, Giuseppe (2006), Libraries, Translations, and 'Canonic' Texts: The Septuagint, Aquila and Ben Sira in the Jewish and Christian Traditions (Supplements to the Journal for the Study of Judaism 109), Leiden/Boston.

Wallraff, Martin (2013), Kodex und Kanon. Das Buch im frühen Christentum (Hans-Lietzmann-Vorlesungen 12), Berlin.

Watts, James W. (1995), “Public Readings and Pentateuchal Law”, in: Vetus Testamentum 45, 540-557.

Weitzmann, Kurt (ed.) (1979), Age of Spirituality. Late Antique and Early Christian Art, Third to Seventh Century: Catalogue of the Exhibition at the Metropolitan Museum of Art, New York.

Wischmeyer, Oda (1995), “Das heilige Buch im Judentum des Zweiten Tempels”, in: Zeitschrift für die neutestamentliche Wissenschaft 86, 218-242. 
Zunz, Leopold (1892), Die gottesdienstlichen Vorträge der Juden, historisch entwickelt. Ein Beitrag zur Alterthumskunde und biblischen Kritik, zur Literatur- und Religionsgeschichte, Frankfurt am Main.

\section{Photo Credits}

Fig. 1: ( Cambridge University Library. 